\title{
A Study on Customized Smart Beauty Recognition and Brand Strategy
}

\author{
Do-Eun Kim ${ }^{1}$, Young-Sam Kim²* \\ ${ }^{1}$ Department of Cosmetics Engineering, Konkuk University, Seoul, Korea \\ ${ }^{2}$ Department of Image Industry, Graduate School of Engineering, Konkuk University, Seoul, Korea
}

\author{
*Corresponding author: Young-Sam Kim, \\ Department of Image Industry, Graduate \\ School of Engineering, Konkuk University, \\ 120 Neungdong-ro, Gwangjin-gu, Seoul \\ 05029, Korea \\ Tel.: +82 24500463 \\ Email: gracehelen@konkuk.ac.kr
}

Received August 13, 2021

Revised September 2, 2021

Accepted September 14, 2021

Published September 30, 2021

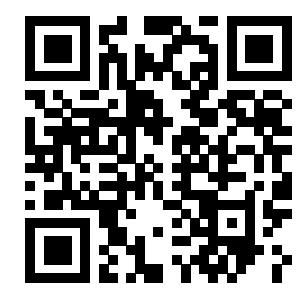

\begin{abstract}
Purpose: This study seeks to discover how customized smart beauty recognition can produce positive results, and to demonstrate that it affects brand attitudes and purchasing intentions of buyers. Pine \& Gilmore's experience theory will be used as a basis for this study. This study focuses on customized cosmetics as a type of beauty product. Methods: Data were gathered from 255 women between the ages 20 and 40 from all over Korea. Different tools were used to analyze the data, including the SPSS WIN 21.0 program, Varimax for regression analysis, and Cronbach's $\alpha$ coefficient for reliability analysis. Differences in characteristics were conducted using a one-way-ANOVA, follow-up verification, and correlation analysis between variables and influence verification. Results: Customized cosmetics helped accurately diagnose and prescribe the consumer's condition with measuring devices. The smart beauty service that the consumer's experienced was face measurement and virtual makeup. In the future, the consumer's would like to experience the effect of skin care before and after skin condition measurement as a smart beauty service. Looking at the impact of Fine \& Gilmore's theory of experience economy on brand attitude and purchase intention, the higher the educational experience $(\beta=0.313)$, the more realistic the experience $(\beta=0.195)$, the higher the aesthetic experience $(\beta=$ $.357)$ and the higher the brand attitude $(\beta=0.667)$. The intention to purchase clearly increases with these positive experiences. Conclusion: This study concluded that although customized cosmetics are highly reliable but expensive, buyers still want to purchase them at a reasonable price. It was also discovered that smart beauty services want improvements in measurement errors, the reliability of the information provided, and the ability to perform additional comparative analysis. Moreover, like Pine \& Gilmore's theory of experience economy, it was determined that the higher the satisfaction consumers have after their experience, the higher the brand image and the intention to purchase. We hope to use this theory as important information for continuing research in the beauty industry.
\end{abstract}

Keywords: Customized cosmetics, Smart beauty, Beauty tech, Experience marketing, brand attitude

\section{Introduction}

최근 세계 경제는 4차 산업혁명 시대로 2016년 다보스 포럼에서'4 차 산업혁명'의 화두가 등장한 이후 기술융합으로 대변되는 산업구조 패러다임의 전환이 빠르게 이루어지고 있다(Won et al., 2018). 제4차 산업혁명은 인공지능(AI), 빅데이터, 사물인터넷(Internet of Things),
모바일 등 다양한 부문의 신기술 융합을 통한 사회의 혁명적 변화를 지칭한다(Park, 2019). 스마트 기술을 활용한 새로운 형태의 정보 커 뮤니케이션은 다양한 형태의 서비스로 삶 속에 파고들었고 이제는 일 상적인 생활 공간에서도 다양한 스마트 디바이스를 어렵지 않게 찾아 볼 수 있게 되었다(Oh et al., 2017). 뷰티 업계에도 증강현실(AR), 가 상현실(VR), 인공지능(AI) 기술을 이용한 상품과 서비스가 출시되고 
있고, 정보통신기술(information and communications technologies, ICT)의 융합으로 빅 데이터, 모바일, IoT 등을 서비스 데이터로 치환하 는 맞춤형 서비스를 제공할 수 있는 $\mathrm{AI}$ 기술 접목이 본격화되고 있다 (Cha \& Han, 2020). 뷰티에 IT기술을 융합한 스마트 뷰티 상품과 서 비스. 이를 일컬어 '스마트 뷰티(Smart Beauty)'또는 '뷰티 테크(Beauty Tech)'라 부른다(Lee \& Kim, 2019). 이처럼 스마트 뷰티 산업에 발 맞 춰 국내에선 2017년 3월30일 보건복지부는 산·학•연 전문가 40여명 이 참여하는 화장품 산업 발전 기획단을 출범하고, 연구개발(R\&D), 해 외진출, 인프라, 제도개선 등 4 개 분과위원회를 구성하여 분기별 정기 회의를 거쳐 화장품 산업의 경쟁력 강화를 위한 지원방안(Lee et al., 2020)을 모색하였다. 이에 따라 식품의약품안전처에서는 화장품법 제 도 개선을 진행하였고 그 핵심 내용 중 하나가 바로 맞춤형화장품의 정의 및 맞춤형화장품 판매업 영역을 신설하는 것이었으며, 2018년 2 월 20 일 이와 같은 내용이 화장품법(일부)개정법률로 국회 본회의를 통과하게 되었다(Kong \& Kim, 2018). 식품의약품안전처가 2020년 3 월부터 맞춤형화장품 제도를 실시하면서 대한민국에는 맞춤형화장품 의 시대가 열리게 되었다(Choi, 2019). 맞춤형 화장품이란 수입 또는 제조된 화장품의 내용물에 다른 내용물이나 식품의약품안전처장이 지 정한 원료를 더하여 혼합한 화장품과 수입 또는 제조된 화장품의 내용 물을 소분(小分)한 화장품이다(Jung \& Kim, 2020). 기존 화장품은 생 산자 중심으로 미리 제품을 대량 생산하여 불특정 다수 소비자에게 만 들어 판매하는 방식이라면(Kang \& Im, 2019), 맞춤형 화장품은 고 객 피부에 맞는 화장품을 사용 횟수, 사용량, 사용 방법까지 처방하여 (Hong \& Kim, 2020), 소비자 중심의 개별 요구에 따라 혼합-소분하 여 판매하는 방식이다(Kang \& Im, 2019). 점점 개인의 취향을 중요시 하는 소비층이 늘어나고 이들이 곧 뷰티 시장의 주 소비층으로 부상하 면서(Lee \& Song, 2020b), 제품 브랜드와의 정신적 자극과 교감, 교류 를 가질 수 있도록 하는 체험적 마케팅으로 변화되고 있다(Lee, 2018).
기존에 체험 마케팅 대다수는 제품 시연이나 단순한 경험의 성격 으로 한시적인 홍보 방식에 머물렀던 과거와 달리 제품을 직접 만져 보거나 발라보지 않고도 모바일 어플리케이션에 $\mathrm{AR}$ 기술을 접목시켜 (Kim, 2017) 가상메이크업을 하거나, 어플리케이터를 장착한 제품들 의 출시(Hwang \& Yoon, 2018)로 피부 측정 및 분석, 데일리 차트 보 관, 화장품 큐레이션, online to offline $(\mathrm{O} 2 \mathrm{O})$ 뷰티 관리 등 개인 맞춤 형 서비스를 제공(Heo et al., 2020)하면서 그 방식이 발전되고 있다. 현대의 소비자들은 구매과정에서 자극되는 감각과 정서를 중시하며 자신의 라이프스타일에 적합한 보다 직접적인 커뮤니케이션 체험 욕 구를 갖는다(Kim et al., 2020). 소비자의 커뮤니케이션이 온 오프라인 으로 확장되며 화장품업체들의 소비자 접점을 찾으려는 노력(Shin \& $\mathrm{Kim}, 2017)$ 을 하고 있다. 긍정적인 서비스품질을 경험 한 고객은 제공 받은 서비스에 만족하며 재구매 의도나 충성도까지 결정하게 된다고 한다(Oh et al., 2017). 참여 경험을 통해 기능적 가치를 대신할 수 있 는 감성적 가치를 제공하고 이를 브랜드 충성도 결정의 핵심 요인으로 간주한다(Kim et al., 2020). Pine \& Gilmore의 저서 고객 체험의 경제 학(The experience economy)에서는 체험을 범용품, 제조품, 서비스의 단계를 거처 상위개념으로 정의 내렸으며, 진정한 의미의 체험은 고객 이 제품의 생산과정에 직접적으로 참여하는 것으로 정의하였다(Lee \& Lee, 2013).

체험에는 단순히 감각적 측면뿐 아니라 엔터테인먼트적 측면, 교육 적 측면, 현실도피적 측면, 미적측면이 존재한다고 하여 차세대 체험 마케팅 전략을 제시하였다(Park et al., 2007). 이는 Schmitt에 비하여 상당히 거시적인 접근법으로서 자사의 제품이 경쟁사들과의 가격전쟁 에 휩쓸려 범용품화 되는 것을 방지하기 위해서는 자사의 제품이나 서 비스에 '체험'이라는 가치를 더해야 한다고 주장했고 이들은 체험을 상 품으로 간주했다(Lee \& Lee, 2013). 소비자는 제품 구매 시 제품의 객 관적 품질보다 주관적으로 판단하고 평가하는 지각된 품질에 의해 제

Table 1. Experience, brand attitude, purchase intent factors, and reliability analysis

\begin{tabular}{|c|c|c|c|c|}
\hline Experience factor & \multirow{2}{*}{ Factor name } & \multirow{2}{*}{ Commonality } & \multirow{2}{*}{ Factor loadings } & \multirow{2}{*}{ Eigen value } \\
\hline Cronbach's $\alpha$ & & & & \\
\hline \multirow{2}{*}{ Educational $(\alpha=0.600)$} & Educational 1 & 0.751 & 0.832 & \multirow{2}{*}{24.149 (1.690) } \\
\hline & Educational 2 & 0.691 & 0.750 & \\
\hline \multirow{2}{*}{ Escapist $(\alpha=0.711)$} & Escapist 1 & 0.811 & 0.873 & \multirow{2}{*}{$22.928(1.605)$} \\
\hline & Escapist 2 & 0.741 & 0.783 & \\
\hline \multirow{3}{*}{ Aesthetic ( $\alpha=0.654)$} & Aesthetic 1 & 0.709 & 0.811 & \multirow{3}{*}{$22.792(1.595)$} \\
\hline & Aesthetic 2 & 0.662 & 0.692 & \\
\hline & Aesthetic 3 & 0.526 & 0.522 & \\
\hline \multirow{3}{*}{$\begin{array}{l}\text { Brand attitude } \\
(\alpha=0.699)\end{array}$} & Brand attitude 1 & 0.841 & 0.909 & \multirow{3}{*}{$39.226(2.354)$} \\
\hline & Brand attitude 2 & 0.571 & 0.601 & \\
\hline & Brand attitude 3 & 0.613 & 0.527 & \\
\hline \multirow{3}{*}{$\begin{array}{l}\text { Purchase Intention } \\
(\alpha=0.757)\end{array}$} & Purchase Intention 1 & 0.701 & 0.793 & \multirow{3}{*}{$27.337(1.640)$} \\
\hline & Purchase Intention 2 & 0.601 & 0.715 & \\
\hline & Purchase Intention 3 & 0.668 & 0.810 & \\
\hline
\end{tabular}


품을 평가하는 경우가 많으며 지각된 품질은 구매 의도에 매우 큰 영 향을 미친다(Lee \& Li, 2021)고 한다. 이는 구매의사 결정과정 중 중요 한 변수로 실제 화장품 구매 의도와 기업의 성과 측정에 중요한 변수 로 고려된다(Oh, 2020). 따라서 본 연구는 이러한 시대적 흐름에 발 맞 추어 국내 맞춤형 스마트 뷰티의 인식 및 개선 방향과 Pine \& Gilmore 의 체험 마케팅 이론을 중심으로 브랜드 태도와 구매의도까지 영향을 미치는지 알아보고자 한다.

\section{Methods}

\section{1. 연구참여자 및 기간}

본 연구는 맞춤형 스마트 뷰티 서비스를 접할 기회가 많은 실제 시 장상황을 반영하여 전국에 거주하는 20-40대 일반인 여성 대상으로 설문조사를 실시하였다. 조사 기간은 2021년 8월 4일부터 동년 8월 5 일까지 2 일 동안 온라인 리서치 전문기관을 통해 설문조사를 실시하여 데이터를 수집하였다. 총 255 부를 배부하여 255 부가 회수되었으며, 설문지 총 255 부를 최종 분석 자료로 사용하였다.

\section{2. 측정 도구}

\section{1) 설문지 구성}

본 연구에서 사용된 설문지는 맞춤형화장품 인식에 대한 Lee \& Song (2020b)의 문항을 참고하였고 스마트 뷰티 인식에 대한 Cha \& Han (2020)의 문항을 Pine과 Gilmore의 체험마케팅 이론에 대한 Park et al., (2007)의 선행연구의 측정항목을 토대로 본 연구의 목적
에 맞게 문항을 수정, 보완하여 재구성하여 제작한 설문지를 사용하였 다. 본 연구의 설문지 구성은 크게 3 가지 요인으로, 조사 대상자의 일 반적 특성 4 문항, 맞춤형 화장품 인식 및 개선 6 문항, 스마트 뷰티 인 식 및 개선 5 문항과 스마트 뷰티 체험에 관한 시나리오를 주어 교육적 체험요인 3 문항, 현실도피적 체험요인 3 문항, 심미적체험요인 3 문항 과 브랜드 태도에 관한 문항 3 문항, 구매의도에 관한 문항 3 문항 이렇 게 총 30 문항으로 구성하였다.

\section{2) 자료 분석}

본 연구의 수집된 자료는 Statistical Package for the Social Science (SPSS) WIN 21.0 프로그램(BM, USA)을 이용하여 분석하였고 분석 기법은 다음과 같다. 첫째, 표본의 인구통계학적특성을 살펴보기 위 해 빈도분석을 실시하였다. 둘째, 설문지의 항목이 측정변수를 측정 하는데 있어 타당한지의 여부를 확인하기 위해 Varimax 직각회전방 법을 통한 요인분석을 실시하였고, 변수들의 신뢰성을 확인하기 위 해 Cronbach's $\alpha$ 계수를 이용하여 신뢰도를 실시하였다. 셋째, 인구 통계학적 특성에 따른 차이점을 확인하기 위해 분산분석(One-wayANOVA)를 실시하였으며, 사후검증의 경우 Scheffe 분석을 실시하였 다. 넷째, 변수들 간의 상관관계를 살펴보기 위해 상관관계 분석을 실 시하였다. 다섯째, 변수들의 영향력을 검증하기 위해 다중회귀분석과 단순회귀분석을 실시하였다.

\section{Results and Discussion}

\section{1. 연구참여자의 일반적 특성}

Table 2. Analysis of age differences

\begin{tabular}{|c|c|c|c|c|c|c|}
\hline Category & Age group & M & SD & $F$ & $P$ & Scheffe \\
\hline \multirow{3}{*}{ Educational experience } & $20-29$ (a) & 3.79 & 0.55 & \multirow{3}{*}{0.414} & \multirow{3}{*}{0.661} & \multirow{3}{*}{-} \\
\hline & $30-39(b)$ & 3.81 & 0.63 & & & \\
\hline & $40-49$ (c) & 3.87 & 0.61 & & & \\
\hline \multirow{3}{*}{ Escapist experience } & $20-29$ (a) & 2.96 & 0.82 & \multirow{3}{*}{5.445} & \multirow{3}{*}{$0.005^{* *}$} & \multirow{3}{*}{$c>a$} \\
\hline & 30-39 (b) & 3.13 & 0.84 & & & \\
\hline & $40-49$ (c) & 3.38 & 0.75 & & & \\
\hline \multirow{3}{*}{ Aesthetic experience } & $20-29$ (a) & 3.36 & 0.58 & \multirow{3}{*}{5.202} & \multirow{3}{*}{$0.006^{* *}$} & \multirow{3}{*}{$c>a, b$} \\
\hline & $30-39$ (b) & 3.35 & 0.58 & & & \\
\hline & $40-49$ (c) & 3.60 & 0.54 & & & \\
\hline \multirow{3}{*}{ Brand attitude } & $20-29$ (a) & 3.33 & 0.63 & \multirow{3}{*}{2.085} & \multirow{3}{*}{0.126} & \multirow{3}{*}{-} \\
\hline & 30-39 (b) & 3.40 & 0.55 & & & \\
\hline & $40-49$ (c) & 3.52 & 0.61 & & & \\
\hline \multirow{3}{*}{ Purchase intention } & $20-29$ (a) & 3.33 & 0.77 & \multirow{3}{*}{1.523} & \multirow{3}{*}{0.220} & \multirow{3}{*}{-} \\
\hline & 30-39 (b) & 3.41 & 0.63 & & & \\
\hline & $40-49$ (c) & 3.51 & 0.66 & & & \\
\hline
\end{tabular}

${ }^{* *} p<0.01$ 
인구통계학적 특성은 연령의 경우 20-29세 69명(27.1\%), 30-39 세 96명(37.6\%), 40-49세 90명(35.3\%)으로 30-39세가 많은 것으 로 나타났다. 거주지역의 경우 서울 78 명(30.6\%), 경기도/인천 85명 (33.3\%), 강원도 3명(1.2\%), 충청도 19명(7.5\%), 전라도 10명(3.9\%), 경상도 60 명 $(23.5 \%)$ 으로 경기도/인천이 많은 것으로 나타났다. 직업의 경우 전문/기술직 32 명(12.5\%), 사무/관리직 102명(40.0\%), 학생 26 명(10.2\%), 영업/서비스직 26명(10.2\%), 전업주부 47명(18.4\%), 기타 22 명(8.6\%)으로 사무/관리직이 많은 것으로 나타났다. 월 평균 소득의 경우 100 만원 미만 60명(23.5\%), 100-200 만원 미만 51명(20.0\%), 200-350 만원 미만 95명(37.3\%), 350-500 만원 미만 29명(11.4\%),
500 만원 이상 20명(7.8\%)으로 200-350 만원 미만이 많은 것으로 나 타났다.

\section{2. 맞춤형 화장품 인식 및 개선}

맞춤형 화장품 인지 여부의 경우 '예' 138 명(54.1\%), '아니오' 117 명 (45.9\%)으로 '예'가 많은 것으로 나타났다. 맞춤형 화장품 이미지의 경 우 기존에 만들어져 있는 제품을 조합해 주는 화장품 26명(10.2\%), 측 정기기를 통해 분석된 결과로 처방해주는 화장품 111 명(43.5\%), 원 하는 성분에 따라 즉석에서 제조해 주는 화장품 87명(34.1\%), 의사 들이 직접 만들어 판매하는 화장품 9 명(3.5\%), 일반 화장품과는 다

Table 3. Analysis of different regions

\begin{tabular}{|c|c|c|c|c|c|c|}
\hline Category & Area & M & SD & $F$ & $p$ & Scheffe \\
\hline \multirow{6}{*}{ Educational experience } & Seoul & 3.85 & 0.57 & \multirow{6}{*}{2.732} & \multirow{6}{*}{$0.020^{*}$} & \multirow{6}{*}{-} \\
\hline & $\begin{array}{l}\text { Gyeonggi-do/ } \\
\text { Incheon }\end{array}$ & 3.92 & 0.60 & & & \\
\hline & Gangwon-do & 2.83 & 0.29 & & & \\
\hline & Chungcheong-do & 3.66 & 0.55 & & & \\
\hline & Jeolla-do & 3.60 & 0.52 & & & \\
\hline & Gyeongsang-do & 3.82 & 0.64 & & & \\
\hline \multirow{6}{*}{ Escapist experience } & Seoul & 3.28 & 0.80 & \multirow{6}{*}{1.049} & \multirow{6}{*}{0.390} & \multirow{6}{*}{-} \\
\hline & $\begin{array}{l}\text { Gyeonggi-do/ } \\
\text { Incheon }\end{array}$ & 3.15 & 0.86 & & & \\
\hline & Gangwon-do & 3.17 & 0.58 & & & \\
\hline & Chungcheong-do & 2.84 & 0.73 & & & \\
\hline & Jeolla-do & 3.35 & 0.58 & & & \\
\hline & Gyeongsang-do & 3.13 & 0.83 & & & \\
\hline \multirow{6}{*}{ Aesthetic experience } & Seoul & 3.47 & 0.59 & \multirow{6}{*}{1.887} & \multirow{6}{*}{0.097} & \multirow{6}{*}{-} \\
\hline & $\begin{array}{l}\text { Gyeonggi-do/ } \\
\text { Incheon }\end{array}$ & 3.49 & 0.57 & & & \\
\hline & Gangwon-do & 2.89 & 0.51 & & & \\
\hline & Chungcheong-do & 3.16 & 0.62 & & & \\
\hline & Jeolla-do & 3.63 & 0.40 & & & \\
\hline & Gyeongsang-do & 3.43 & 0.55 & & & \\
\hline \multirow{6}{*}{ Brand attitude } & Seoul & 3.41 & 0.61 & \multirow{6}{*}{2.579} & \multirow{6}{*}{$0.027^{*}$} & \multirow{6}{*}{-} \\
\hline & $\begin{array}{l}\text { Gyeonggi-do/ } \\
\text { Incheon }\end{array}$ & 3.46 & 0.56 & & & \\
\hline & Gangwon-do & 2.44 & 0.96 & & & \\
\hline & Chungcheong-do & 3.19 & 0.67 & & & \\
\hline & Jeolla-do & 3.57 & 0.47 & & & \\
\hline & Gyeongsang-do & 3.49 & 0.57 & & & \\
\hline \multirow{6}{*}{ Purchase intention } & Seoul & 3.47 & 0.66 & \multirow{6}{*}{1.542} & \multirow{6}{*}{0.177} & \multirow{6}{*}{ - } \\
\hline & $\begin{array}{l}\text { Gyeonggi-do/ } \\
\text { Incheon }\end{array}$ & 3.40 & 0.73 & & & \\
\hline & Gangwon-do & 2.44 & 1.02 & & & \\
\hline & Chungcheong-do & 3.32 & 0.56 & & & \\
\hline & Jeolla-do & 3.47 & 0.42 & & & \\
\hline & Gyeongsang-do & 3.48 & 0.67 & & & \\
\hline
\end{tabular}

${ }^{*} p<0.05$. 
른 기능성이 있는 화장품 22 명(8.6\%)으로 측정기기를 통해 분석된 결 과로 처방해주는 화장품이 높게 나타났다. 맞춤형 화장품 구매이유 의 경우 '나의 상태를 정확히 진단하여 만든 화장품이라 신뢰가 가서' 159 명(62.4\%), '일반 화장품 보다 효능, 효과가 좋을 것 같아서' 47 명 (18.4\%), '일반 화장품보다 성분이 더 좋을 것 같아서' 47명(18.4\%), 현재 사용 중인 일반 화장품(피부 트러블 등)에 만족하지 못해서' 19 명 (7.5\%), '차별화된 제품에 대한 관심과 흥미' 17 명(6.7\%)으로 '나의 상 태를 정확히 진단하여 만든 화장품이라 신뢰가 가서'가 많은 것으로 나타났다. 맞춤형 화장품으로 필요한 제품으로는 기초 화장품 149 명 (58.4\%), 기능성 화장품 71명(27.8\%), 색조 화장품 20명(7.8\%), 모발 화장품 10명(3.9\%), 바디용 화장품 4명(1.6\%), 방향용 제품 1 명(0.4\% 로 나타났다. 맞춤형 화장품 우려되는 부분의 경우 '구매방식이 번거롭 거나 구입 경로가 어려울 것이다' 37 명(14.5\%), '일반 화장품 보다 가격
이 너무 높을 것이다' 160 명(62.7\%), '품질이 보장되지 않고 교환/환불 이 어려울 것이다' 40 명(15.7\%), '일반 화장품과 별 차이가 없을 것이 다' 13 명(5.1\%), '맞춤형이어도 나에게 맞지 않을 것이다' 5 명(2.0\%)으 로 '일반 화장품 보다 가격이 너무 높을 것이다'가 많은 것으로 나타났 다. 맞춤형 화장품 바라는 부분의 경우 합리적인 가격 133 명(52.2\%), 구입의 편리성 32 명(12.5\%), 품목의 다양성 13 명 $(5.1 \%)$, 맞춤 방식의 전문성 및 신뢰성 69 명(27.1\%), 품질의 고급화 및 차별화된 취향 반영 8 명(3.1\%)으로 합리적 가격이 많은 것으로 나타났다.

\section{3. 스마트 뷰티 인식 및 개선}

체험해본 스마트 뷰티 서비스의 경우 두피 측정 5 명(10.4\%), 피부 상태 측정 23 명(47.9\%), 얼굴 측정 및 가상메이크업 27명(56.3\%), 체 형 측정 및 가상 피팅 8 명(16.7\%), 가상 헤어 스타일링 11명(22.9\%)으

Table 4. Analysis of professional differences

\begin{tabular}{|c|c|c|c|c|c|c|}
\hline Category & Job & $M$ & $\mathrm{SD}$ & $F$ & $p$ & Scheffe \\
\hline \multirow{6}{*}{ Educational experience } & Specialized/Technical (a) & 3.92 & 0.46 & \multirow{6}{*}{3.912} & \multirow{6}{*}{$0.002^{* *}$} & \multirow{6}{*}{$c>f$} \\
\hline & Office/Management(b) & 3.89 & 0.60 & & & \\
\hline & Student (c) & 4.06 & 0.54 & & & \\
\hline & Sales/service (d) & 3.62 & 0.48 & & & \\
\hline & Housewife (e) & 3.81 & 0.70 & & & \\
\hline & Others (f) & 3.43 & 0.54 & & & \\
\hline \multirow{6}{*}{ Escapist experience } & Specialized/Technical (a) & 3.31 & 0.66 & \multirow{6}{*}{1.187} & \multirow{6}{*}{0.316} & \multirow{6}{*}{-} \\
\hline & Office/Management (b) & 3.18 & 0.92 & & & \\
\hline & Student (c) & 3.13 & 0.69 & & & \\
\hline & Sales/service (d) & 2.90 & 0.87 & & & \\
\hline & Housewife (e) & 3.30 & 0.71 & & & \\
\hline & Others (f) & 3.00 & 0.77 & & & \\
\hline \multirow{6}{*}{ Aesthetic experience } & Specialized/Technical (a) & 3.54 & 0.45 & \multirow{6}{*}{3.643} & \multirow{6}{*}{$0.003^{* *}$} & \multirow{6}{*}{-} \\
\hline & Office/Management (b) & 3.51 & 0.59 & & & \\
\hline & Student (c) & 3.50 & 0.56 & & & \\
\hline & Sales/service (d) & 3.13 & 0.49 & & & \\
\hline & Housewife $(e)$ & 3.51 & 0.56 & & & \\
\hline & Others (f) & 3.14 & 0.64 & & & \\
\hline \multirow{6}{*}{ Brand attitude } & Specialized/Technical (a) & 3.50 & 0.57 & \multirow{6}{*}{1.977} & \multirow{6}{*}{0.083} & \multirow{6}{*}{-} \\
\hline & Office/Management (b) & 3.45 & 0.59 & & & \\
\hline & Student (c) & 3.53 & 0.58 & & & \\
\hline & Sales/service (d) & 3.18 & 0.57 & & & \\
\hline & Housewife $(e)$ & 3.50 & 0.57 & & & \\
\hline & Others (f) & 3.20 & 0.70 & & & \\
\hline \multirow{6}{*}{ Purchase intention } & Specialized/Technical (a) & 3.57 & 0.52 & \multirow{6}{*}{1.230} & \multirow{6}{*}{0.296} & \multirow{6}{*}{-} \\
\hline & Office/Management (b) & 3.44 & 0.75 & & & \\
\hline & Student (c) & 3.44 & 0.70 & & & \\
\hline & Sales/service (d) & 3.28 & 0.58 & & & \\
\hline & Housewife $(e)$ & 3.47 & 0.57 & & & \\
\hline & Others $(\mathrm{f})$ & 3.48 & 0.80 & & & \\
\hline
\end{tabular}

${ }^{* *} p<0.01$ 
로 얼굴측정이 많은 것으로 나타났다. 체험하고 싶은 스마트 뷰티 서 비스(다중응답)의 경우 두피 측정을 통한 두피관리 전·후에 대한 효과 정보 71 명(27.8\%), 피부 상태 측정을 통한 피부관리 전·후에 대한 효 과정보 148 명(58.0\%), 얼굴 측정을 통한 메이크업 컬러 및 스타일 시 뮬레이션 107명(42.0\%), 체형 측정 및 가상 피팅을 통한 체형관리 효 과정보 및 스타일 시뮬레이션 65 명(25.5\%), 가상 헤어 스타일링을 통한 헤어 컬러 및 스타일 시뮬레이션 64 명(25.1\%), 네일 측정을 통 한 네일아트 컬러 및 스타일 시뮬레이션 4명(1.6\%)으로 피부 상태 측 정을 통한 피부관리 전·후에 대한 효과정보가 많은 것으로 나타났다. 스마트 뷰티 서비스 중요부분의 경우 제공 정보의 신뢰성이 103 명 (40.4\%), 제공 정보의 최신성 23 명(9.0\%), 제공 정보의 다양성 54 명 (21.2\%), 유사 제품군의 연관성 15 명(5.9\%), 제공 서비스의 접근성 24 명 $(9.4 \%)$, 제공 서비스의 편리성 36 명(14.1\%)으로 제공 정보의 신뢰 성이 높은 것으로 나타났다. 스마트 뷰티 체험 후 개선할 사항의 경우 쉬운 조작 변경 및 속도 35명(13.7\%), 측정의 오류 94명(36.9\%), 측정 후 연관성 35 명(13.7\%), 시각적 요소 44명(17.3\%), 색감 자동 보정 6 명(2.4\%), 실제 사이즈에 따른 사용자별 적용 41 명(16.1\%)으로 측정
의 오류가 많은 것으로 나타났다. 스마트 뷰티 추가기능의 경우 검색 기능 12 명(4.7\%), 후기 작성 기능 26 명(10.2\%), 제품 구매 기능 46명 (18.0\%), 쉬운 설명 및 조작 기능 48명(18.8\%), 비교 분석 기능 90명 (35.3\%), 다양한 뷰티 정보 연계 서비스 33 명(12.9\%)으로 비교 분석 기능이 많은 것으로 나타났다.

\section{4. 측정도구의 타당성 및 신뢰도 분석}

본 연구에서 활용한 측정 변수의 타당성 및 신뢰도 검증을 위해 요 인분석 및 신뢰도 분석을 실시하였다. 요인분석 방법으로는 주성분분 석(principal components analysis)추출모델을 사용하였고, 회전방식 의 경우 직각회전 방식인 배리 맥스(Varimax)회전 방식을 이용하였 다. 정보의 손실을 최소화하기 위해 요인적재 값이 미달인 항목들은 제거 후 분석을 실시하였다. 척도의 타당성과 더불어 추가로 요인분 석을 통해 선정된 설문 항목에 대한 신뢰도(reliability) 검증을 실시하 였다. 신뢰도 분석의 경우 크론바하 알파(Cronbach's $\alpha$ ) 계수를 이용 해 검증을 실시하였다. 체험, 브랜드 태도, 구매의도에 대한 요인분석 및 신뢰도 검증 결과는 Table 1 과 같다.

\section{Table 5. Analysis of differences according to monthly average income}

\begin{tabular}{|c|c|c|c|c|c|c|}
\hline Category & Job & M & SD & $F$ & $P$ & Scheffe \\
\hline \multirow{5}{*}{ Educational experience } & Less than $100(a)$ & 3.77 & 0.72 & \multirow{5}{*}{3.144} & \multirow{5}{*}{$0.015^{*}$} & \multirow{5}{*}{-} \\
\hline & Less than $100-200(b)$ & 3.70 & 0.62 & & & \\
\hline & Less than $200-350$ (c) & 3.81 & 0.47 & & & \\
\hline & Less than 350-500 (d) & 4.05 & 0.62 & & & \\
\hline & More than 500 (f) & 4.13 & 0.56 & & & \\
\hline \multirow{5}{*}{ Escapist experience } & Less than 100 (a) & 3.11 & 0.77 & \multirow{5}{*}{0.676} & \multirow{5}{*}{0.609} & \multirow{5}{*}{ - } \\
\hline & Less than $100-200(b)$ & 3.11 & 0.78 & & & \\
\hline & Less than 200-350 (c) & 3.17 & 0.83 & & & \\
\hline & Less than $350-500(d)$ & 3.22 & 0.82 & & & \\
\hline & More than $500(f)$ & 3.43 & 1.00 & & & \\
\hline \multirow{5}{*}{ Aesthetic experience } & Less than $100(a)$ & 3.29 & 0.64 & \multirow{5}{*}{3.786} & \multirow{5}{*}{$0.005^{* *}$} & \multirow{5}{*}{$d>a$} \\
\hline & Less than $100-200(b)$ & 3.42 & 0.59 & & & \\
\hline & Less than 200-350 (c) & 3.41 & 0.51 & & & \\
\hline & Less than 350-500 (d) & 3.71 & 0.49 & & & \\
\hline & More than 500 (f) & 3.68 & 0.57 & & & \\
\hline \multirow{5}{*}{ Brand attitude } & Less than 100 (a) & 3.34 & 0.58 & \multirow{5}{*}{2.991} & \multirow{5}{*}{$0.019^{*}$} & \multirow{5}{*}{$f>a, b$} \\
\hline & Less than $100-200(b)$ & 3.33 & 0.70 & & & \\
\hline & Less than 200-350 (c) & 3.42 & 0.49 & & & \\
\hline & Less than 350-500 (d) & 3.51 & 0.64 & & & \\
\hline & More than 500 (f) & 3.82 & 0.65 & & & \\
\hline \multirow{5}{*}{ Purchase intention } & Less than $100(a)$ & 3.31 & 0.68 & \multirow{5}{*}{3.192} & \multirow{5}{*}{$0.014^{*}$} & \multirow{5}{*}{$f>a, b$} \\
\hline & Less than $100-200(b)$ & 3.31 & 0.77 & & & \\
\hline & Less than 200-350 (c) & 3.43 & 0.54 & & & \\
\hline & Less than 350-500 (d) & 3.53 & 0.79 & & & \\
\hline & More than 500 (f) & 3.87 & 0.69 & & & \\
\hline
\end{tabular}

${ }^{* *} p<0.01,{ }^{*} p<0.05$ 
1)체험의 요인분석 및 신뢰도 분석

요인분석결과 고유값 1.0 이상으로 추출된 요인은 총 3 개의 요인으 로 구분하였으며, 각각의 요인명은 '교육적체험', '현실도피적체험', 심미적체험'이다. 표본 적합도를 판단하는 $\mathrm{KMO}$ 값은 0.770 으로 나 타났으며, Bartlett의 구형성 검정 결과 근사카이제곱이 406.686으로 자유도 21 일 때, 유의수준 $5 \%$ 이내에서 유의확률 0.000 으로 나타나 요인분석을 수행하기에 적합한 것으로 나타났다. 또한 각 요인별 측 정항목의 요인분석결과 요인적재치가 0.4 이상의 수치를 보이고 있어 측정항목의 타당성이 충분한 것으로 판단되었다. 신뢰도를 분석 결과 Cronbach's $\alpha$ 의 각각의 계수도 모두 0.6보다 높이 나타남으로써 내적 일관성이 있는 항목으로 구성되어 있음을 보여주어 문제없이 분석에 투입하였다.

\section{2) 브랜드태도 및 구매의도 요인분석 및 신뢰도 분석}

브랜드태도 및 구매의도에 대한 요인분석 및 신뢰도 검증 결과 Table 1 과 같다. 요인분석결과 고유값 1.0 이상으로 추출된 요인은 총 2 개의 요인으로 구분하였으며, 각각의 요인명은 '브랜드태도', '구매 의도'이다. 표본 적합도를 판단하는 $\mathrm{KMO}$ 값은 0.865 로 나타났으며, Bartlett의 구형성 검정 결과 근사카이제곱이 483.783 으로 자유도 15 일 때, 유의수준 $5 \%$ 이내에서 유의확률 0.000 으로 나타나 요인분석을 수행하기에 적합한 것으로 나타났다. 또한 각 요인별 측정항목의 요 인분석결과 요인적재치가 0.4 이상의 수치를 보이고 있어 측정항목의 타당성이 충분한 것으로 판단되었다. 신뢰도를 분석 결과 Cronbach's $\alpha$ 의 각각의 계수도 모두 0.6 보다 높이 나타남으로써 내적 일관성이 있는 항목으로 구성되어 있음을 보여주어 문제없이 분석에 투입하였 다.

\section{Pine \& Gilmore의 체험경제 이론이 브랜드 태도와 구매의도에 미치는 영향}

1) 인구통계학적 특성에 따른 차이분석

연령, 거주지, 직업, 월 평균 소득에 따라 교육적체험, 현실도피적 체험, 심미적체험, 브랜드태도, 구매의에 차이를 살펴보기 위해 분산 분석(one-way-ANOVA)를 실시하였다. 사후검정의 경우 Scheffe 분 석을 실시하였다.

먼저 연령에 따른 현실도피적 체험의 경우 통계적으로 유의한 것 으로 나타났다 $(F=5.445, p<0.01)$. 구체적으로 살펴보면 40-49세 $(\mathrm{M}=3.38, \mathrm{SD}=0.75)$ 의 평균값이 가장 높게 나타났고, 다음은 30-39 세( $\mathrm{M}=3.13, \mathrm{SD}=0.84), 20-29$ 세 $(\mathrm{M}=2.96, \mathrm{SD}=0.82)$ 순으로 나타 났다. Scheffe 사후분석 결과 40-49 세와 20-29세가 통계적으로 유 의한 수준에서 차이가 있는 것으로 나타났다 $(p<0.01)$. 연령에 따른 심미적 체험의 경우 통계적으로 유의한 것으로 나타났다 $(F=5.202$, $p<0.01)$. 구체적으로 살펴보면 $40-49$ 세 $(\mathrm{M}=3.60, \mathrm{SD}=0.54)$ 의 평 균값이 가장 높게 나타났고, 다음은 20-29세 $(\mathrm{M}=3.36, \mathrm{SD}=0.58)$, 30-39세 $(\mathrm{M}=3.35, \mathrm{SD}=0.58)$ 순으로 나타났다. Scheffe 사후분석
결과 40-49세와 20-29세, 40-49세와 30-39세가 통계적으로 유 의한 수준에서 차이가 있는 것으로 나타났다( $p<0.05)$. 이외 교육적 체험 $(F=0.414, p>0.05)$, 브랜드태도 $(F=2.085, p>0.05)$, 구매의도 $(F=1.523, p>0.05)$ 의 경우 통계적으로 유의미하지 않은 것으로 나타 났다(Table 2).

거주지에 따른 교육적 체험의 경우 통계적으로 유의한 것으로 나타 났다( $F=2.732, p<0.05)$. 구체적으로 살펴보면 경기도/인천( $\mathrm{M}=3.92$, $\mathrm{SD}=0.60)$ 의 평균값이 가장 높게 나타났고, 다음은 서울 $(\mathrm{M}=3.85$, $\mathrm{SD}=0.57)$, 경상도 $(\mathrm{M}=3.82, \mathrm{SD}=0.64)$, 충청도 $(\mathrm{M}=3.66, \mathrm{SD}=0.55)$, 전라도 $(\mathrm{M}=3.60, \mathrm{SD}=0.52)$, 강원도 $(\mathrm{M}=2.83, \mathrm{SD}=0.29)$ 순으로 나 타났다. 브랜드태도의 경우 통계적으로 유의한 것으로 나타났다 $(F=2.579, p<0.05)$. 구체적으로 살펴보면 전라도 $(\mathrm{M}=3.57, \mathrm{SD}=0.47)$ 의 평균값이 가장 높게 나타났고, 다음은 경상도 $(\mathrm{M}=3.49, \mathrm{SD}=0.57)$, 경기도/인천( $\mathrm{M}=3.46, \mathrm{SD}=0.56)$, 서울 $(\mathrm{M}=3.41, \mathrm{SD}=0.61)$, 충청 도 $(\mathrm{M}=3.19, \mathrm{SD}=0.67)$, 강원도 $(\mathrm{M}=2.44, \mathrm{SD}=0.96)$ 순으로 나타났 다. 이외 현실도피적 체험 $(F=1.049, p>0.05)$, 심미적체험 $(F=1.887$, $p>0.05)$. 구매의도 $(F=1.542, p>0.05)$ 의 경우 통계적으로 유의미하지 않은 것으로 나타났다(Table 3 ).

직업에 따른 교육적 체험의 경우 통계적으로 유의한 것으로 나타났 다 $(F=3.912, p<0.05)$. 구체적으로 살펴보면 학생 $(\mathrm{M}=4.06, \mathrm{SD}=0.54)$ 의 평균값이 가장 높게 나타났고, 다음은 전문/기술직 $(\mathrm{M}=3.92$, $\mathrm{SD}=0.46)$, 사무/관리직 $(\mathrm{M}=3.89, \mathrm{SD}=060)$, 전업주부 $(\mathrm{M}=3.81$, $\mathrm{SD}=0.70)$, 영업/서비스직 $(\mathrm{M}=3.62, \mathrm{SD}=0.48)$, 기타 $(\mathrm{M}=3.43$, $\mathrm{SD}=0.54)$ 순으로 나타났다. Scheffe 사후분석 결과 학생과 기타가 통계적으로 유의한 수준에서 차이가 있는 것으로 나타났다 $(p<0.01)$. 심미적 체험의 경우 통계적으로 유의한 것으로 나타났다 $(F=3.643$, $p<0.01)$. 구체적으로 살펴보면 전문/기술직 $(\mathrm{M}=3.54, \mathrm{SD}=0.45)$ 의 평균값이 가장 높게 나타났고, 다음은 전업주부 $(\mathrm{M}=3.51, \mathrm{SD}=0.56)$ 와 사무관리직 $(\mathrm{M}=3.51, \mathrm{SD}=0.59)$, 학생 $(\mathrm{M}=3.50, \mathrm{SD}=0.56)$, 기 타 $(\mathrm{M}=3.14, \mathrm{SD}=0.64)$, 영업/서비스직 $(\mathrm{M}=3.13, \mathrm{SD}=0.49)$ 순으 로 나타났다. 이외 현실도피적 체험( $F=1.187, p>0.05)$, 브랜드태도 $(F=1.977, p>0.05)$, 구매의도 $(F=1.230, p>0.05)$ 의 경우 통계적으로 유의미하지 않은 것으로 나타났다(Table 4).

월 평균 소득에 따른 현실도피적 체험의 경우 통계적으로 유의미하 지 않은 것으로 나타났다 $(F=0.676, p>0.05)$. 이외는 통계적으로 유의 한 것으로 나타났다. 월 평균 소득에 따른 차이 분석 결과는 Table 5 와 같다.

2) 상관관계 분석

교육적체험, 현실도피적 체험, 심미적체험, 브랜드태도, 구매의 도의 상관관계를 분석하였다. 변수 간의 영향 관계를 조사하기 전 에 상관관계를 분석하는 것은 통계적 유의성을 알아보고자 하는 사 전 조치이다. 분석결과 Table 6 과 같이 모든 변수는 통계적으로 유 의한 수준에서 정(+)적 상관관계를 보이는 것으로 나타났다. 교육적 
체험 $(\mathrm{r}=0.496, p<0.001)$, 현실도피적체험 $(\mathrm{r}=0.465, p<0.001)$, 심미 적체험 $(\mathrm{r}=0.577, p<0.001)$ 은 브랜드 태도와 정 $(+)$ 적 상관관계가 있 는 것으로 나타났다. 이러한 브랜드태도의 경우 구매의도 $(\mathrm{r}=0.667$, $p<0.001)$ 와 정(+)적 상관관계가 있는 것으로 나타났다.

\section{3) 체험이 브랜드태도에 미치는 영향}

체험이 브랜드 태도에 미치는 영향을 분석하기 위해 다중회귀분 석을 실시한 결과 Table 7과 같다. 회귀분석을 실시하기 위하여 종속 변수의 자기상관과 독립변수 간의 다중공선성을 검토하였다. 종속변 수의 자기 상관은 Durbin-Watson 지수를 이용하였으며, DurbinWatson 지수가 1.942로 나타나 자기상관이 없이 독립적이다. 독립 변수간 다중공선성은 $\mathrm{VIF}$ (분산팽창요인) 지수를 이용하였고, 독립변 수 간 VIF지수는 1.166-1.515로 10 미만이므로 다중공선성이 없는 것으로 나타났다. 따라서 본 데이터는 회귀분석을 실시하기에 적합 하다. 다중회귀분석 결과 $(F=69.043, p<0.001)$ 교육적체험(p<0.01), 현실도피적체험 $(p<0.001)$, 심미적체험 $(p<0.001)$ 은 브랜드태도에 정 $(+)$ 의 유의한 영향을 주었다. 즉, 교육적체험이 높을수록( $\beta=0.313)$, 현실도피적체험이 높을수록 $(\beta=0.195)$, 심미적체험이 높을수록 $(\beta$ $=0.357)$ 브랜드태도가 높아진다. 이중 심미적체험이 가장 큰 영향을
주었고, 다음은 교육적체험, 현실도피적체험 순으로 나타났다. 이러 한 변수들이 종속변수를 설명하는 설명력은 $45.2 \%$ 이다.

4) 브랜드 태도가 구매의도에 미치는 영향

브랜드태도가 구매의도에 미치는 영향을 분석하기 위해 단순회 귀분석을 실시한 결과는 Table 8과 같다. 회귀분석을 실시하기 위 하여 종속변수의 자기상관을 검토하였다. 종속변수의 자기 상관 은 Durbin-Watson 지수를 이용하였으며, Durbin-Watson 지수가 2.146으로 나타나 자기상관이 없이 독립적이다. 따라서 본 데이터는 회귀분석을 실시하기에 적합하다. 단순회귀분석 결과 $(F=202.703$, $p<0.001)$ 브랜드태도 $(p<0.001)$ 은 구매의도에 정 $(+)$ 의 유의한 영향을 주었다. 즉, 브랜드태도가 높을수록 $(\beta=0.667)$ 구매의도가 높아진다. 이러한 변수가 종속변수를 설명하는 설명력은 $44.52 \%$ 이다.

\section{Conclusion}

본 연구는 맞춤형 스마트 뷰티 인식과 개선 방향과 Pine \& Gilmore 의 체험이론을 중심으로 브랜드 태도와 구매의도에 영향이 미치는

Table 6. Correlation analysis results

\begin{tabular}{|c|c|c|c|c|c|}
\hline \multirow{2}{*}{ Category } & \multicolumn{5}{|c|}{ Experience factor } \\
\hline & Educational & Escapist & Aesthetic & Brand attitude & Purchase intention \\
\hline Educational & 1 & & & & \\
\hline Escapist & $0.255^{* * *}$ & 1 & & & \\
\hline Aesthetic & $0.371^{* * *}$ & $0.530^{* * *}$ & 1 & & \\
\hline Brand attitude & $0.496^{* * *}$ & $0.465^{* * *}$ & $0.577^{* * *}$ & 1 & \\
\hline Purchase intention & $0.486^{* * *}$ & $0.346^{* * *}$ & $0.479^{* * *}$ & $0.667^{* * *}$ & 1 \\
\hline
\end{tabular}

Table 7. Regression analysis results of experience on brand attitudes

\begin{tabular}{|c|c|c|c|c|c|c|c|}
\hline \multirow{2}{*}{ Model } & \multicolumn{2}{|c|}{$\begin{array}{l}\text { Unstandardized } \\
\text { coefficients }\end{array}$} & \multirow{2}{*}{$\begin{array}{c}\begin{array}{c}\text { Standardization } \\
\text { coefficients }\end{array} \\
\beta\end{array}$} & \multirow[t]{2}{*}{$t$} & \multirow{2}{*}{ Sig. } & \multicolumn{2}{|c|}{$\begin{array}{l}\text { Collinearity } \\
\text { statistics }\end{array}$} \\
\hline & B & SE & & & & TOL & VIF \\
\hline (constant) & 0.496 & 0.211 & & 2.350 & 0.020 & & \\
\hline Educational & 0.312 & 0.050 & 0.313 & 6.214 & $0.000^{* * *}$ & 0.858 & 1.166 \\
\hline Escapist & 0.143 & 0.040 & 0.195 & 3.536 & $0.000^{* * *}$ & 0.715 & 1.398 \\
\hline Aesthetic & 0.372 & 0.060 & 0.357 & 6.209 & $0.000^{* * *}$ & 0.660 & 1.515 \\
\hline
\end{tabular}

${ }^{* * *} p<0.001$.

Table 8. Regression analysis results on the effect of brand attitude on purchase

\begin{tabular}{|c|c|c|c|c|c|}
\hline \multirow[t]{2}{*}{ Model } & \multicolumn{2}{|c|}{$\begin{array}{l}\text { Unstandardized } \\
\text { Coefficients }\end{array}$} & \multirow{2}{*}{$\begin{array}{c}\begin{array}{c}\text { Standardization } \\
\text { Coefficients }\end{array} \\
\beta\end{array}$} & \multirow{2}{*}{$t$} & \multirow{2}{*}{ Sig. } \\
\hline & B & SE & & & \\
\hline (constant) & 0.826 & 0.185 & & 4.462 & 0.000 \\
\hline Brand attitude & 0.759 & 0.053 & 0.667 & 14.237 & $0.000^{* * *}$ \\
\hline
\end{tabular}


지 검증하는데 목적을 두고, 전국에 거주하는 20-40대 일반인 여성 255 명을 대상으로 설문조사를 실시하였다. 수집된 자료는SPSS WIN 21.0 프로그램을 이용하여 분석하였으며, Varimax를 통한 요인분 석, Cronbach's $\alpha$ 계수를 이용하여 신뢰도분석, 특성에 따른 차이점 은 One-way-ANOVA, 사후검증으로 Scheffe분석, 변수들간 상관관 계 분석과 영향력 검증을 위해 다중회귀분석과 단순회귀분석으로 분 석하여 다음과 같은 결과를 얻었다.

첫째, 맞춤형 화장품 인지 여부의 경우 138 명(54.1\%)으로 예가 많 은 것으로 나타났지만 '아니오'가 117명(45.9\%)으로 맞춤형 화장품 에 대한 인식이 그리 높지 않은 것을 알 수 있었다. 이는 아직 대중 화되어 있지 않기 때문이라 사료된다. 맞춤형 화장품 이미지는 111 명 $(43.5 \%)$ 이 측정기기를 통해 분석된 결과로 처방해주는 화장품으 로 높게 나타났고 맞춤형 화장품 구매이유는 159 명(62.4\%)이 '나의 상태를 정확히 진단하여 만든 화장품이라 신뢰가 가서'가 많은 것으 로 나타나 맞춤형 화장품의 신뢰도가 높고 인식이 긍정적임을 알 수 있었다. 맞춤형 화장품으로 필요한 제품으로는 기초 화장품 149 명 (58.4\%), 기능성 화장품71명(27.8\%)으로 나타나 화장품 구매의 목 적이 피부에 직접적 개선효과를 기대하기 때문이라고 사료된다. 맞 춤형 화장품 우려되는 부분의 경우 160 명(62.7\%)으로 일반 화장품 보다 가격이 너무 높을 것이다가 압도적으로 높게 나와 Lee \& Song (2020b)의 연구 결과와도 일치한다. 맞춤형 화장품 바라는 부분의 경 우 합리적인 가격 133 명 $(52.2 \%)$ 으로 앞서 우려되는 부분에서 일반 화장품 보다 가격이 너무 높을 것이다 라고 인식한 결과라고 사료된 다.

둘째, 체험해본 스마트 뷰티 서비스의 경우 $56.3 \%$ 으로 얼굴 측 정 및 가상 메이크업으로 나타나 Cha \& Han (2020)의 연구와 같은 결과를 얻었다. 또한 체험하고 싶은 스마트 뷰티 서비스(다중응답) 는 피부 상태 측정을 통한 피부관리 전·후에 대한 효과정보 148 명 (58.0\%), 얼굴 측정을 통한 메이크업 컬러 및 스타일 시뮬레이션 107 명(42.0\%)으로 각각 나타났다. 스마트 뷰티 체험 후 개선할 사항은 측정의 오류 94명(36.9\%), 스마트 뷰티 서비스에서 가장 중요한 부 분은 제공 정보의 신뢰성이 103 명(40.4\%)으로 나타나 아직 정확하고 쉽게 인식되는 기술과 정보에 대한 신뢰도가 낮음을 알 수 있었다. 스마트 뷰티 추가기능의 경우 비교 분석 기능 90 명(35.3\%)이 많은 것 으로 나타나 비교분석의 세부적인 기능을 넣으면 소비자의 만족을 높 일 수 있을 것으로 예상한다.

셋째, Pine \& Gilmore의 체험경제 이론이 브랜드 태도와 구매의도 에 미치는 영향을 보면 연령에 따라 현실도피적 Scheffe 사후분석 결 과, 40-49세와 20-29세가 통계적으로 유의한 수준에서 차이가 있 는 것으로 나타났고( $p<0.01)$, 심미적 체험의 경우 40-49세와 20-29 세, 40-49세와 30-39세가 통계적으로 유의한 수준에서 차이가 있 는 것으로 나타났다 $(p<0.05)$.

거주지에 따른 교육적 체험 $(F=2.732, p<0.05)$, 브랜드태도 $(F=2.579, p<0.05)$ 의 경우 통계적으로 유의한 것으로 나타났다. 직
업에 따른 교육적 체험 $(F=3.912, p<0.05)$, 심미적 체험( $F=3.643$, $p<0.01)$ 의 경우 통계적으로 유의한 것으로 나타났다.

월 평균 소득에 따른 교육적 체험 $(F=3.144, p<0.05)$, 심미적 체 험 $(F=3.786, p\langle 0.01)$, 브랜드태도 $(F=2.991, p\langle 0.05)$, 구매의도 $(F=3.192, p<0.05)$ 의 경우 통계적으로 유의한 것으로 나타났다. 교 육적체험( $\mathrm{r}=0.496, p<0.001)$, 현실도피적 체험( $(\mathrm{r}=.465, p\langle 0.001)$, 심미적체험 $(\mathrm{r}=0.577, p<0.001)$ 은 브랜드 태도와 정 $(+)$ 적 상관관계가 있는 것으로 나타나 브랜드태도의 경우 구매의도 $(\mathrm{r}=0.667, p<0.001)$ 와 정(+)적 상관관계가 있는 것으로 나타났다.

교육적체험이 높을수록 $(\beta=0.313)$, 현실도피적 체험이 높을수록 $(\beta=0.195)$, 심미적체험이 높을수록 $(\beta=0.357)$ 브랜드태도가 높아진 다. 이중 심미적체험이 가장 큰 영향을 주었고, 다음은 교육적체험, 현실도피적 체험 순으로 나타났다. 브랜드태도가 높을수록 $(\beta=.667)$ 구매의도가 높아진다는 것을 알 수 있었다.

이상의 결과를 미루어 보면 맞춤형 화장품은 비싸다는 인식이 있 지만 대체적으로 긍정적이고 신뢰도가 높은 것을 알 수 있었고, 스마 트 뷰티 서비스는 측정오류의 개선과 제공 정보의 신뢰성과 비교 분 석 기능을 바라는 것을 알 수 있었다.

또한 Pine \& Gilmore의 체험경제 이론처럼 소비자가 직접 체험 후 얻은 만족도가 높을수록 브랜드 이미지와 구매 의도가 높아지는 것을 알 수 있었다.

일반 화장품과 차별화된 맞춤형 스마트 뷰티의 효과를 높이기 위 해서는 소비자가 직접 구매 과정을 적극적으로 참여할 수 있도록 유 도해야 하고 일회성이 아닌 지속적인 맞춤형 스마트 뷰티 서비스를 제공하는 전략을 세워야 한다고 사료된다.

본 연구는 모든 한국 여성들에게 일반화하기에는 표본의 수가 다 소 부족함이 있었으나 소비자들의 맞춤형 스마트 뷰티에 대한 인식과 개선 방향, 체험 마케팅의 기초 자료로 활용되기를 기대한다.

\section{Author's contribution}

DEK performed experiments and DEK and YSK designed, analyzed data, and wrote the manuscript together. All figures are created by the authors. All authors read and approved the final manuscript.

\section{Author details}

Do-Eun Kim (Graduate student), Department of Cosmetics Engineering, Graduate School of Konkuk University, 120 Neungdong-ro Gwangjin-gu, Seoul 05029, Korea; Young-Sam Kim (Professor), Department of Image Industry, Graduate School of Engineering, Konkuk University, 120 Neungdong-ro Gwangjin-gu, Seoul 05029, Korea. 


\section{References}

Cha MK, Han JS. Impact on brand loyalty and buying intention in the fourth industrial revolution experience helped cosmetic brand of device Al beauty. Journal of the Korean Society of Cosmetics and Cosmetology, 10: 187-197, 2020.

Choi Et. A study on the perception of the customized cosmetics and the cystem of preparation manager who dispense the customized cosmetics. Journal of The Korean Society of cosmetology, 25: 1229-1238. 2019.

Heo MR, Lee KJ, Wang S, Cheon DU, Ham SP. Development process of Al-based personalized beauty service platform. Korea Society of IT Services, 2020: 766-770, 2020.

Hong JY, Kim YS. Improving the system of the national qualification test for customized cosmetic preparation managers. Asian Journal of Beauty and Cosmetology, 18: 341-354, 2020.

Hwang EH, Yoon CS. A basic study on real status of total smart mirror (TSM) with loT-based augmented reality (AR): focused on beauty industry. Journal of the Korea Society of Digital Industry and Information Management, 14: 1-14, 2018.

Jung HW, Kim JD. A study on implementation status of and improvement plans for customized cosmetics preparation manager licenses. Journal of the Korean Society of Cosmetics and Cosmetology, 10: 247-262, 2020.

Kim GM. A study on the changes of the fourth industrial revolution and global beauty market. Journal of Cultural Product \& Design, 50: 221-231, 2017.

Kim JH, Lee SH, Sung YH. A case study on the types of customized cosmetics: focused on Bernd H. Schmitt's strategic experiential modules (SEMs). Journal of Cultural Product \& Design, 63: 27-41, 2020.

Kong SM, Kim MS. Usage of customized cosmetics and preferred customized cosmetic types by age in female consumers. Journal of Investigative Cosmetology, 14: 331 342, 2018.

Kang MA, Im EJ. The effects of cognitive evaluation and emotional evaluation of customized cosmetics on purchase behavior. Journal of Investigative Cosmetology, 15: 191-202, 2019.

Lee EJ, Kim YA. The influence of experience of smart beauty service in 20 s female college students on brand attitude and loyalty. Journal of Basic Design \& Art, 20: 377-392, 2019.

Lee YS, Lee MH, Lee JH, Nam HW. A study on the personalized cosmetics and beauty devices consumer for perception/ preference survey model. Design Research, 5: 70-80, 2020.

Lee MS, Song TI. A study on reliability and purchase behavior of customized cosmetic: focus on 20 to 50 aged female living in Gwangju. Journal of the Korean Society of Design Culture, 26: 283-293, 2020.

Lee $\mathrm{S}$. Effects of drugstore experience factors on customers' satisfaction with their shop-visit experience. Asian Journal of Beauty and Cosmetology, 16: 267-276, 2018.

Lee BR, Lee JK. A study on low-priced cosmetics brand in space direction of applying the theory of marketing experience pine \& gilmore. Journal of the Korea Institute of Spatial Design, 8: 49-58, 2013.

Lee EJ, Li SH. Research on cosmetic quality perception and satisfaction according to consumer characteristics. Journal of Convergence for Information Technology, 11: 216-224, 2021.

Oh MS, Han GH, Choi HJ, Seo YH. Improvement of user experience and service value enhancement using smart mirror. Journal of Advanced Navigation Technology, 21: 394-401, 2017.

Oh YJ. Influence of a cosmetic company's eco-friendly activities on consumers' purchase intention through the mediating effects of perceived image. Asian Journal of Beauty and Cosmetology, 18: 149-161, 2020.

Park JS. Impact of smart beauty care service industry on the activation of skin beauty industry in the fourth industrial revolution: mainly on skin beauty app. The Journal of Humanities and Social Science 21, 10: 615-628, 2019.

Park SK, Park JH, Cha TH. Effects of experience on enjoyment, satisfaction, and revisit intention: pine and Gilmore's experience economy perspective. Advertising Research, 0 : 55-78, 2007.

Shin HI, Kim JS. Development smart cosmetic design applied by loT technology. Journal of Cultural Product \& Design, 49:125-132, 2017.

Won JW, Han GH, Oh MS. A study on strategic direction of beauty care service using smart mirror. Journal of Communication Design, 63: 61-74, 2018. 
국문초록

\section{맞춤형 스마트 뷰티 인식과 브랜드 전략에 관한 연구}

김도은 ${ }^{1}$, 김영삼 ${ }^{2 *}$

${ }^{1}$ 건국대학교 화장품공학과, 서울, 한국

${ }^{2}$ 건국대학교 산업대학원 이미지산업학과, 서울, 한국

목적: 본 연구는 맞춤형 스마트 뷰티 인식과 개선방향에 대해 알아보고, Pine \& Gilmore의 체험이론을 중심으로 브랜드 태도와 구 매의도에 영향을 미치는지 검증하고자 한다. 방법: 전국에 거주하는 20-40대의 여성 255명을 대상으로 자료를 수집하였고, SPSS WIN 21.0 프로그램을 이용하여 분석하였으며, Varimax를 통한 요인분석, Cronbach's $\alpha$ 계수를 이용하여 신뢰도분석, 특성에 따른 차이점은 One-way-ANOVA, 사후검증으로 Scheffe분석, 변수들간 상관관계 분석과 영향력 검증을 위해 다중회귀분석과 단순회 귀분석을 실시하였다. 결과: 맞춤형화장품은 측정기기로 나의 상태를 정확히 진단하여 처방해주는 화장품으로 인식했고, 체험해본 스마트 뷰티 서비스는 얼굴 측정 및 가상 메이크업으로 나타났다. 앞으로 체험하고 싶은 맞춤형 스마트 뷰티 서비스는 피부상태 측 정을 통한 피부관리 전·후에 대한 효과 정보였고, Pine \& Gilmore의 체험경제 이론이 브랜드 태도와 구매의도에 미치는 영향을 보 면 교육적체험 $(\beta=0.313)$, 현실도피적체험 $(\beta=0.195)$, 심미적체험이 높을수록 $(\beta=0.357)$ 브랜드태도가 높아지고, 브랜드태도가 높을 수록 $(\beta=0.667)$ 구매의도가 높아진다는 것을 알 수 있었다. 결론: 맞춤형 화장품의 신뢰도가 높지만 비싸다는 인식에 합리적인 가격 을 바라는 것을 알 수 있었고 스마트 뷰티 서비스는 측정오류의 개선과 제공 정보의 신뢰성, 추가적으로 비교 분석 기능을 바라는 것으로 나타났다. 또한 Pine \& Gilmore의 체험경제 이론처럼 소비자가 직접 체험 후 얻은 만족도가 높을수록 브랜드 이미지와 구매 의도가 높아지는 것을 알 수 있었다. 이러한 이론을 근거로 뷰티 분야에 기초 자료로 활용하길 기대한다.

핵심어: 맞춤형화장품, 스마트뷰티, 뷰티테크, 체험 마케팅, 브랜드 태도

\section{참고문헌}

강민아, 임은진. 맞춤형 화장품에 대한 인지적 평가와 감성적 평가가 구매행동에 미치는 영향. 대한미용학회지, 15: 191202,2019

공선미, 김민신. 연령별 여성소비자의 맞춤형화장품 사용실태 및 선호유형. 대한미용학회지, 14: 331-342, 2018. 김곡미. 4차 산업혁명과 글로벌 뷰티시장의 변화에 관한 연구. 상품문화디자인학연구, 50: 221-231, 2017. 김정훈, 이수행, 성열홍. 맞춤형 화장품 유형별 사례 연구: 전략적 체험 모듈을 중심으로. 상품문화디자인학연구, $63: 27-$ $41,2020$.

박수경, 박지혜, 차태훈. 체험요소(4Es)가 체험즐거움, 만족도, 재방문에 미치는 영향: Pine과 Gilmore의 체험경제이론

(Experience Economy)을 중심으로. 광고연구, 0: 55-78, 2007.

박정수. 4 차 산업혁명 시대의 스마트 뷰티케어 서비스 산업이 피부미용업의 활성화에 미치는 영향: 피부미용 앱을 중심으

로. 인문사회 21, 10: 615-628, 2019.

신희인, 김장수. IoT 기능을 적용한 스마트 화장품 디자인 개발 연구. 상품문화디자인학연구, 49: 125-132, 2017. 이미선, 송태임. 맞춤형 화장품의 신뢰도 및 구매행동 연구: 광주광역시 20 50대 여성을 중심으로. 한국디자인문화학회 지, 26: 283-293, 2020.

이보람, 이정교. Pine \& Gilmore의 체험마케팅 이론을 적용한 중저가 화장품 브랜드 공간연출에 관한 연구. 한국공간디자 인학회 논문집, 8: 49-58, 2013.

이상은. 드럭스토어 체험 요인이 매장 방문 경험 만족도에 미치는 영향. 아시안뷰티화장품학술지, 16: 267-276, 2018. 이은주, 리순화. 소비자 특성에 따른 화장품 품질 인식 및 만족도 연구. 융합정보논문지, 11: 216-224, 2021. 
이은진, 김연아. 20 대 여대생의 스마트 뷰티 서비스 경험이 브랜드 태도 및 충성도에 미치는 영향. 기초조형학연구, 20 : 377-392, 2019.

이영신, 이민희, 이지훈, 남현우. 개인 맞춤형 화장품 및 뷰티 디바이스 소비자 인식도/선호도 조사 모델 연구. 한국디자인 리서치, 5: 70-80, 2020.

오문석, 한규훈, 최현준, 서영호. 스마트 미러를 이용한 사용자 경험 개선과 서비스 제공가치 증진 방안. 한국항행논문지, 21: 394-401, 2017.

오유진. 화장품 기업의 친환경활동이 지각된 이미지를 매개로 화장품 구매의도에 미치는 영향. 아시안뷰티화장품학술지, 18: 149-161, 2020.

원종욱, 한규훈, 오문석. 스마트 미러를 활용한 뷰티케어 서비스 전략방향 연구. 커뮤니케이션디자인학연구, 63: 61-74, 2018.

정효원, 김주덕. 맞춤형화장품조제관리사 자격증 시행실태와 개선방안에 관한 연구. 한국화장품미용학회지, $10: 247-$ $262,2020$.

차민경, 한지수. 4 차 산업 $\mathrm{AI}$ 뷰티 기기 체험이 화장품 브랜드 애호도와 구매의도에 미치는 영향. 한국화장품미용학회지, 10: 187-197, 2020.

최에스더. 맞춤형 화장품과 맞춤형화장품조제관리사 제도에 관한 인식도 조사. 한국미용학회지, 25: 1229-1238, 2019. 허미리, 이경전, 왕상, 천동욱, 함승필. 인공지능 기술 기반 맞춤형 뷰티 서비스 플랫폼 개발 프로세스. 한국IT서비스학회 학술대회논문집, 2020: 766-770, 2020.

홍지유, 김영삼. 맞춤형화장품조제관리사 국가자격시험제도 개선방향성에 대한 연구. 아시안뷰티화장품학술지, 18: $341-$ $354,2020$.

황은희, 윤천성. IoT기반의 증강현실을 활용한 Total 스마트 미러 기초 실태조사 연구: 뷰티산업을 중심으로. 디지털산업 정보학회논문지, $14: 1-14,2018$. 


\section{中文摘要}

\section{定制化智能美妆识别与品牌策略研究}

金到垠 ${ }^{1}$, 金永三 $^{2 *}$

${ }^{1}$ 建国大学化妆品工学科, 首尔, 韩国

2建国大学产业大学院影像产业学科, 首尔, 韩国

目的: 调查定制型智能美容认识和改善方向, 以Pine \& Gilmore的体验理论为中心, 验证是否影响品牌态度和 购买意图。方法: 以居住在全国的255名20-40岁女性为对象收集资料, 利用SPSS WIN 21.0程序进行分析, 利 用Varimax进行因素分析, 利用Cronbach'sa系数进行信任度分析, 特证差异采用One-way-ANOVA, 事后验证 采用Scheffe分析, 为了验证变量间的关系和影响力, 实施了多重回归分析和单纯回归分析。结果: 量身定制的 化妆品是用测量仪器准确诊断我的状态并开具药方的化妆品, 体验过的智能美妆服务表现为脸部测量及虚拟妆 容。今后想体验的定制型智能美容服务是关于皮肤状况测量前后护肤效果的信息, 从Pine \& Gilmore的体验经 济理论对品牌态度和购买意图的影响表明, 教育体验（ $\beta=0.313 ）$ ，逃避现实的体验（ $\beta=0.195 ）$ ，审美体验越 高 $(\beta=0.357)$ 品牌态度越高, 品牌态度越高 $(\beta=0.667)$ 可以看出购买意图越高。结论: 可以看出, 定制化妆 品的信赖度很高, 但是价格昂贵, 因此希望得到合理的价格。并且发现智能美容服务需要改进测量误差、提供 信息的可靠性和额外的比较分析功能。此外, 与 Pine \& Gilmore 的体验经济理论一样, 发现直接体验后获得的 满意度越高，品牌形象和购买意愿就越高。基于这一理论，预计它将被用作美容领域的基础数据。

关键词: 定制型化妆品, 智能美容, 美容技术, 体验营销, 品牌态度 
